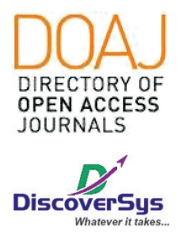

Published by DiscoverSys

\section{Hubungan berat tas dengan gangguan muskuloskeletal pada siswa SMAN 4 Denpasar, Bali-Indonesia}

CrossMark

\author{
I Putu Putrayasa Wiguna, ${ }^{1 *}$ I Putu Gede Adiatmika ${ }^{2}$
}

\title{
ABSTRACT
}

Introduction: Several major subjects contained in the current curriculum in high school that make students must bring a lot of book. This causes the bag used by high school students become heavier, which can cause musculoskeletal disorders in high school. This research aims to find the relationship between the weight of bags used to school with musculoskeletal disorders in high school students.

Method: This research is an analytic cross-sectional design of the high school students from October to December 2015. The level of musculoskeletal disorders was obtained using a Nordic Body
Map questionnaire. Pearson Correlation test used to find out the relationship between weight bag with musculoskeletal disorders.

Result: The result was found that the weight of bags have a relationship with musculoskeletal disorders in high school students. Results of the analysis of 91 samples showed a $p$-value $=0.02$, which means that there is a statistically significant relationship $(p<0.05)$. Conclusion:Weight bag has a relationship with musculoskeletal disorders in high school students, where the increasing weight bag will affect the severity of musculoskeletal disorders that appear on the subject.

Keywords: musculoskeletal disorders, school bag weight, senior high school

Cite This Article: Wiguna, I.P.P., Adiatmika, I.P.G. 2019. Hubungan berat tas dengan gangguan muskuloskeletal pada siswa SMAN 4 Denpasar, Bali-Indonesia. Intisari Sains Medis 10(2): 338-341. D0l: 10.15562/ism.v10i2.388

\section{ABSTRAK}

Latar Belakang: Mata pelajaran utama yang terdapat pada kurikulum yang berlaku di sekolah menengah atas (SMA) membuat siswa harus membawa buku dalam jumlah cukup banyak. Hal tersebut menyebabkan tas yang digunakan oleh para siswa menjadi lebih berat, sehingga dapat menimbulkan gangguan muskuloskeletal. Penelitian ini bertujuan untuk mencari hubungan antara berat tas yang digunakan ke sekolah dengan gangguan muskuloskeletal pada siswa SMA.

Metode: Penelitian ini merupakan penelitian analitik cross-sectional yang dilakukan pada bulan Oktober hingga Desember 2015. Gangguan muskuloskeletal diukur menggunakan kuesioner Nordic Body Map. Uji Pearson Correlation digunakan untuk mencari tahu hubungan berat tas dengan gangguan muskuloskeletal.

Hasil: Hasil analisis dari 91 sampel menunjukkan nilai $p=0,02$, yang berarti bahwa ada hubungan berat tas dengan gangguan muskuloskeletal $(p<0,05)$.

Simpulan: Berat tas memiliki hubungan dengan gangguan muskuloskeletal pada siswa SMA, dimana semakin bertambahnya berat tas akan mempengaruhi beratnya gangguan muskuloskeletal yang muncul pada subjek.
1Program Studi Pendidikan Dokter, Fakultas Kedokteran, Universitas Udayana, Bali, Indonesia

${ }^{2}$ Bagian IImu Faal, Fakultas Kedokteran, Universitas Udayana, Bali, Indonesia

${ }^{*}$ Correspondence to:

I Putu Putrayasa Wiguna, Program Studi Pendidikan Dokter, Fakultas Kedokteran, Universitas Udayana, Bali, Indonesia

putrayasawiguna@gmail.com

Diterima: $15-12-2018$

Disetujui: 04-02-2019

Diterbitkan: 01-08-2019
Kata kunci: gangguan muskuloskeletal, berat tas, sekolah menengah atas

Cite Pasal Ini: Wiguna, I.P.P., Adiatmika, I.P.G. 2019. Hubungan berat tas dengan gangguan muskuloskeletal pada siswa SMAN 4 Denpasar, BaliIndonesia. Intisari Sains Medis 10(2): 338-341. D0I: 10.15562/ism.v10i2.388

\section{PENDAHULUAN}

Sekolah menengah atas (SMA) merupakan salah satu jenjang pendidikan yang ada di Indonesia. Beberapa mata pelajaran utama yang terdapat pada kurikulum yang berlaku saat ini seperti Bahasa Indonesia, Bahasa Inggris, ilmu pengetahuan alam, ilmu pengetahuan sosial, Pendidikan Pancasila dan Kewarganegaraan, matematika dan lain sebagainya membuat siswa-siswi harus membawa buku yang berjumlah cukup banyak dalam satu hari. Hal tersebut menyebabkan tas yang digunakan oleh para pelajar sekolah menengah atas menjadi lebih berat, sehingga dapat menimbulkan gangguan muskuloskeletal pada pelajar sekolah menengah atas.

Menurut World Health Organization (WHO) definisi gangguan muskuloskeletal (Musculoskeletal Disorders/MSDs) adalah gangguan otot, tendon, sendi, ruas tulang belakang, saraf perifer, dan sistem vaskuler yang dapat terjadi tiba-tiba dan akut maupun secara perlahan dan kronis. ${ }^{1}$ 
Tas merupakan sarana wajib bagi setiap pelajar sebagai alat yang berfungsi untuk membawa berbagai keperluan dalam mengikuti kegiatan belajar di sekolah. Berbagai jenis tas digunakan oleh siswa SMA. Jenis tas yang dominan digunakan adalah tas selempang dan tas ransel. Dibalik fungsinya yang mempermudah untuk membawa banyak barang, terdapat masalah yang timbul jika membawa tas dengan beban yang terlalu berat. Salah satu keluhan yang cukup sering terjadi berupa gangguan muskuloskeletal. ${ }^{2}$

Berdasarkan penelitian yang dilaksanakan oleh Mahendrayani, dkk. di Denpasar pada siswa sekolah dasar (SD) dan sekolah menengah pertama (SMP) pada 67 responden, didapatkan bahwa $58,1 \%$ atau sebanyak 36 responden mengalami nyeri punggung bagian bawah. Sedangkan responden yang membawa tas sekolah dengan kategori berat ( $\geq 15 \%$ dari berat badan) sebanyak 29 responden, atau sebanyak $46,8 \%{ }^{3}$ Sedangkan penelitian yang dilakukan di Belanda pada tahun 2003 yang melibatkan 745 remaja pada dua puskesmas yang berbeda menunjukkan bahwa sekitar 45\% mengeluhkan nyeri di bagian leher, bahu, maupun punggung. $6 \%$ dilaporkan mengalami keluhan yang berat pada leher dan / atau bahu, dan $7 \%$ mengalami keluhan punggung yang berat pada anak-anak sekolah. ${ }^{4}$ Berat tas yang dapat disarankan untuk para siswa tidak lebih dari 10\% berat badan. ${ }^{5}$ Oleh karena itu tujuan penelitian ini adalah mencari hubungan antara berat tas yang digunakan ke sekolah dengan gangguan muskuloskeletal pada siswa SMA.

\section{METODE PENELITIAN}

Penelitian ini merupakan penelitian analytic cross-sectional dengan populasi target dari penelitian ini adalah seluruh siswa SMA. Subjek penelitian adalah siswa SMAN 4 Denpasar tahun 2015. Kriteria pemilihan subjek berdasarkan syaratsyarat, yaitu kriteria inklusi. Kriteria inklusi adalah siswa yang memakai tas punggung dan bersedia berpartisipasi sebagai subjek penelitian serta menandatangani informed consent. Instrumen penelitian adalah kuesioner dengan variabel terikat berupa gangguan muskuloskeletal, variabel bebas berupa berat tas diperoleh melalui pengukuran menggunakan alat ukur timbangan, dan variabel kontrol berupa data jenis kelamin, usia, dan berat badan diukur menggunakan instrumen Nordic Body Map (NBM) dengan 28 opsi yang sebelumnya telah dimodifikasi.

Sampel penelitian dipilih dengan menggunakan metode probability sampling yaitu simple random.

Analisis data dilakukan dengan menggunakan analisis univariat dan bivariat. Karena data yang disajikan merupakan data nominal, maka uji hipotesis yang digunakan untuk penelitian ini adalah uji korelasi Pearson (Pearson Correlation).

\section{HASIL}

Berdasarkan hasil penelitian, diperoleh data bahwa jumlah perempuan ditemukan lebih banyak $(57,1 \%)$ dibandingkan laki-laki $(42,9 \%)$. Kategori umur yang paling banyak ditemukan pada subjek adalah 16 tahun (61,5\%). Sedangkan berdasarkan kategori IMT, sebagian besar siswa-siswi SMAN 4 Denpasar memiliki indeks massa tubuh normal $(97,8 \%)$. Sedangkan siswa-siswi yang memiliki IMT di bawah normal ditemukan hanya dua orang $(2,2 \%)$, serta tidak ditemukan responden dengan IMT berlebih (overweight). Berat tas punggung yang dibawa oleh siswa kelas XI SMAN 4 Denpasar berkisar antara 2 kilogram hingga 5 kilogram, di mana ditemukan rerata dan simpang baku berat tas siswa tersebut adalah 3,88 $\pm 0,49$ kilogram. Persentase berat beban tas masing-masing subjek dihitung dengan cara membagi berat tas dengan berat badan subjek dikalikan dengan seratus persen. Menurut perhitungan didapatkan rerata dan simpang baku persentase berat beban tas sebesar $6,98 \pm 0,79 \%$. Sementara itu, gangguan muskuloskeletal berdasarkan kuesioner Nordic Body Map yang ditemukan pada siswa kelas XI SMAN 4 Denpasar cukup tinggi, yaitu dengan rata-rata dan simpang baku $36,04 \pm 5,45$. Hasil karakteristik dijabarkan pada Tabel 1 .

Menurut lokasi gangguan muskuloskeletal, ditemukan frekuensi keluhan terbanyak pada bagian punggung, bahu dan leher. Selengkapnya dijabarkan pada Gambar 1.

Analisis hubungan berat beban tas dengan gangguan muskuloskeletal, terlebih dahulu dilakukan uji untuk mengetahui normalitas data, yaitu dengan uji Kolmogorov-Smirnov.

Hasil uji normalitas didapatkan hasil nilai $\mathrm{p}$ berat beban tas sebesar 0,781 ( $p>0,05)$, begitu pula dengan hasil nilai p gangguan muskuloskeletal sebesar 0,682 ( $p>0,05)$. Dengan demikian dapat disimpulkan bahwa kedua variabel tersebut berdistribusi normal. Hasil uji normalitas dijabarkan pada Tabel 2.

Hasil uji Pearson Correlation dijabar pada Tabel 3. Hasil uji Pearson Correlation didapatkan nilai $r$ sebesar 0,244 dengan nilai $p$ sebesar 0,02 . Dari hasil tersebut, dapat diinterpretasikan terdapat korelasi positif lemah antara berat tas dengan gangguan muskuloskeletal pada siswa kelas XI SMAN 4 Denpasar. Korelasi positif berarti bahwa peningkatan berat beban tas akan mempengaruhi semakin beratnya gangguan muskuloskeletal yang muncul pada subjek. Meskipun demikian, 
Tabel 1 Distribusi Frekuensi Karakteristik Siswa-Siswi SMAN 4 Denpasar

\begin{tabular}{lcc}
\hline Karakteristik Responden & Frekuensi (n) & Persentase (\%) \\
\hline Jenis Kelamin & 39 & 42,9 \\
$\quad$ Laki-laki & 52 & 57,1 \\
$\quad$ Perempuan & & \\
Indeks Massa Tubuh & 2 & 2,2 \\
$\quad$ Underweight & 89 & 97,8 \\
Normal & 0 & 0 \\
Overweight & & \\
Umur & 1 & 1,1 \\
14 & 27 & 29,7 \\
15 & 56 & 61,5 \\
16 & 7 & 7,7 \\
17 & Rerata & Simpang Baku \\
& 3,88 & 0,49 \\
Berat Tas Punggung (Kg) & 6,98 & 0,79 \\
Persentase Berat Beban Tas (\%) & 36,04 & 5,45 \\
Gangguan Muskuloskeletal & & \\
\hline
\end{tabular}

Tabel 2 Hasil uji normalitas

\begin{tabular}{lc}
\hline Parameter & $\mathbf{p}$ \\
\hline Berat Tas & 0,781 \\
Gangguan Muskuloskeletal & 0,682 \\
\hline
\end{tabular}

Tabel 3 Hasil uji Pearson Correlation antara berat beban tas dengan gangguan musculoskeleta

\begin{tabular}{llcc}
\hline Parameter & n & r & p \\
\hline Gangguan Muskuloskeletal & 91 & 0,244 & 0,020 \\
Berat Beban Tas & 91 & 0,244 & 0,020 \\
\hline
\end{tabular}

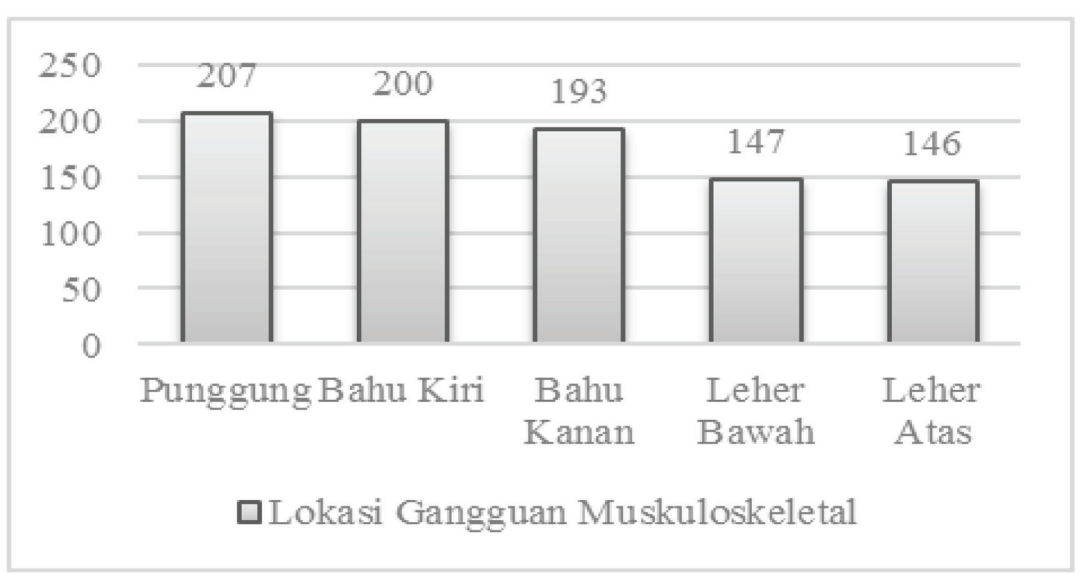

Gambar 1 Distribusi Frekuensi Karakteristik Siswa-Siswi SMAN 4 Denpasar

korelasi tersebut berhubungan lemah oleh karena nilai $r$ berada diantara 0 sampai 0,3 . Nilai $p$ yang lebih kecil dari 0,05 menunjukkan terdapat hubungan yang signifikan secara statistik antara kedua variabel.

\section{PEMBAHASAN}

Pada penelitian yang telah dilakukan, didapatkan bahwa rata-rata berat tas yang dibawa oleh subjek adalah 3,88 kilogram. Rata-rata berat tas pada penelitian ini ditemukan sedikit lebih tinggi dibandingkan dengan penelitian pembanding yang sebelumnya dilakukan di Iran. ${ }^{6}$ Sementara presentase berat tas dari berat badan pada penelitian yang dilakukan oleh Mahendrayani, dkk. di Denpasar terhadap siswa SD dan SMP, didapatkan, dari 62 orang, responden terbanyak yang membawa tas sekolah dengan kategori berat $(\geq 15 \%$ dari berat badan) sebanyak 29 responden (46,8\%). Responden terbanyak berada pada posisi duduk dengan tidak bersandar sebanyak 37 responden $(59,7 \%),{ }^{3,6}$ Hal tersebut diduga dikarenakan pada penelitian pembanding subjek yang diteliti merupakan siswa SD dan SMP. Sementara itu, pada studi yang dilakukan oleh peneliti, subjek yang diteliti merupakan siswa SMA, sehingga diduga pada penelitian ini, subjek memiliki keperluan akademik yang lebih tinggi, jadi berat tas yang dibawa oleh siswa tersebut cenderung lebih berat. Meskipun demikian, menurut rata-rata persentase berat beban tas, hasil yang ditemukan pada penelitian ini lebih rendah dibandingkan dengan standar berat beban tas yang direkomendasikan, yaitu $10 \%$ dari berat badan. Pada penelitian ini, persentase berat beban tas pada siswa adalah $6,98 \%$. Hasil tersebut cukup serupa dengan penelitian pembanding yang dilaksanakan oleh Samshoddini, dkk. di mana ditemukan ratarata persentase berat beban tas pada siswa SMP adalah 7,1\%. ${ }^{6}$ Pada penelitian ini, ditemukannya berat beban tas yang lebih rendah dibandingkan dengan penelitian pembanding diduga oleh karena adanya perbedaan usia dan berat badan antara kedua subjek. Dikarenakan siswa SMP yang lebih muda memiliki berat badan yang lebih rendah, maka berat tas cenderung menjadi lebih berat. Sedangkan, berat tas yang lebih rendah dibandingkan dengan standar global diduga dikarenakan oleh pengukuran penelitian yang dilakukan hanya sekali. Padahal, berat tas yang dibawa oleh siswa dapat bervariasi setiap harinya.

Menurut keterangan yang diperoleh dari salah satu subjek, dinyatakan pula bahwa pada saat pengambilan data dilakukan, banyaknya buku pelajaran yang dibawa tidak sebanyak pada hari lainnya. Berdasarkan gangguan muskuloskeletal yang dialami oleh siswa kelas XI SMAN 4 Denpasar, ditemukan hasil gangguan muskuloskeletal yang cukup tinggi menurut kuesioner Nordic Body Map. Apabila dijabarkan berdasarkan lokasi 
yang mengalami gangguan muskuloskeletal, lokasi paling sering yang mengalami keluhan adalah pada punggung, bahu, dan leher. Hasil tersebut serupa dengan penelitian yang telah dilakukan oleh Mahendrayani, dkk. di Denpasar pada siswa SD dan SMP. ${ }^{3}$ Pada penelitian ini, lokasi tersebut sering mengalami keluhan diduga oleh karena mayoritas siswa menggunakan tas berjenis ransel, di mana titik tumpuan terbesar dari tas jenis tersebut memang terdapat pada ketiga lokasi tersebut. Gangguan muskuloskeletal yang muncul pada siswa kelas XI SMAN 4 Denpasar berkaitan dengan berat tas.

Menurut hasil uji korelasi, semakin meningkatnya berat tas akan mempengaruhi semakin beratnya gangguan muskuloskeletal yang muncul pada subjek. Penelitian oleh Mahendrayani, dkk. Dan oleh Legiran, ditemukan bahwa, meskipun kebanyakan subjek memiliki berat tas yang di bawah standar rata-rata rekomendasi berat tas, namun gangguan muskuloskeletal yang dialami oleh siswa ternyata ditemukan cukup tinggi.,3,7,9 Hal tersebut diduga karena penyebab munculnya gangguan muskuloskeletal pada siswa dapat disebabkan oleh banyak faktor, seperti kelelahan yang pada akhirnya menimbulkan masalah fisik, mental, maupun emosional pada siswa SMA tersebut.

\section{SIMPULAN DAN SARAN}

Berdasarkan hasil penelitian, dapat disimpulkan bahwa ada hubungan antara berat tas dengan gangguan muskuloskeletal pada siswa kelas XI SMAN 4 Denpasar, dimana semakin bertambahnya berat tas akan mempengaruhi beratnya gangguan muskuloskeletal yang muncul pada subjek dengan nilai $0,02(\mathrm{p}<0,05)$. Lokasi tersering yang mengalami gangguan muskuloskeletal adalah punggung, bahu dan leher.

Untuk menangani munculnya gangguan muskuloskeletal yang disebabkan oleh berat beban tas, peneliti menyarankan agar siswa lebih mengatur skala prioritas dalam membawa keperluan yang menunjang kegiatan belajar-mengajar, sehingga tas yang dibawa tidak berlebihan. Jika ada rasa nyeri, bisa mengistirahatkan bahu, punggung dan leher dari tas yang berlebih atau menggunakan obat anti nyeri. Apabila keluhan yang dirasakan sangat berat, disarankan untuk memeriksakan diri ke dokter.

\section{DAFTAR PUSTAKA}

1. Arifandhy TW, Risqa RD, Armasastra B. The Relation between Risk Factors and Musculoskeletal Impairment in Dental Students: a Preliminary Study. Journal of Dentistry Indonesia. 2011;18(2):33-37.

2. Oviedo PR, Ravina AR, Ríos MP, García FB, Fernández DG, Alonso AF, Núñez IC, Pacios PG, Turiso J. School children's backpacks, back pain and back Pathologies. Arch Dis Child. 2012;97:730-732.

3. Mahendrayani LI, Purnawati S, Andayani N. Hubungan Berat Tas dengan Nyeri Punggung Bawah pada Anak Sekolah Umur 12-14 Tahun di Denpasar. E-Medika Udayana. 2015;4(2):1-5.

4. Gent CD, Joselien JCM, de Rover CM., Hira S, Remy A, de Vet HCW. The Weight of Schoolbags and the Occurrence of Neck, Shoulder, and Back Pain in Young Adolescents. Spine. 2003;28(9):916-921.

5. Rai A, Agarawal S. Back Problems Due To Heavy Backpacks in School Children. IOSR Journal Of Humanities And Social Science (IOSR-JHSS). 2013;10(6):22-26.

6. Shamsoddini AR, Hollisaz MT, Hafezi R. Backpack Weight and Musculoskeletal Symptoms in Secondary School Students, Tehran, Iran. Iranian J Publ Health. 2010;39(4):120-125.

7. Legiran L. Berat Tas Punggung Dan Prevalensi Nyeri punggung Pada Siswa Sekolah Dasar. E-jurnal Palembang. 2012; 2(1):8-12.

8. Bhargah A, Muiarta M. Perbaikan intensitas cahaya mempercepat waktu reaksi pada siswa kelas enam sekolah dasar nomor 8 dauh puri Denpasar. Jurnal Ergonomi Indonesia (The Indonesian Journal of Ergonomics). 2016;2(1):18-23.

9. Bhargah A, Muliarta M, Prabawa IPY, Manuaba IBAP, Bhargah V. Post-exercise hypotension, phenomenon in elderly after aerobic exercise. JGPT. 2018;10(6):323-327.

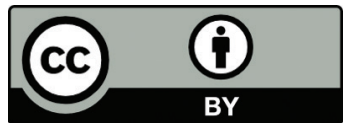

This work is licensed under a Creative Commons Attribution 